\title{
COMPREHENSIVE COMPARISON BETWEEN THE QING IMPERIAL GARDEN AND THE ENGLISH LANDSCAPE GARDEN IN THE 18TH CENTURY: A CULTURAL HERITAGE STUDIES APPROACH
}

\author{
Yongsheng Yin $^{12}$ \\ 1 College of Humanities, University of Exeter, Exeter,UK - y.yin@exeter.ac.uk \\ 2 School of Architecture,Tianjin University, Tianjin, China - yysshanshui@gmail.com
}

Commission II, WG II/8

KEY WORDS: Qing Imperial Garden, English Landscape Garden, Cultural Heritage, Views of Nature, Cultural History, Values

\begin{abstract}
:
In 17-1 $8^{\text {th }}$ century, the spread of the image of the Qing Imperial Garden witnessed the cross-cultural exchanges and promoted the development of English Landscape Garden style. The reciprocal 'far away foreign land' between Chinese and British cultures and the influence of historical context had caused the discrepant view of European on Chinese gardens. This project focuses on the differences of cultural heritage values found in the two kinds of gardens: from the design of space and structure, poems and paintings representing designers' concepts, humanities factors, design conception, gardening elements and etc. Which hopes to fill up the gaps of relevant studies and stress the importance of documentation for gardens between the East and West. There are three aspects to illustrate the inner differences under the surface similarities between the two kinds of gardens. Firstly, the distortion and discontinuity through out the introduction and translation. This research attempts to cross-examine such an argument through an investigation into the journey to the West by the carrier of Chinese Imperial garden ideas. Then the meaning of 'views of nature' in the English Landscape Garden was inconsistent with the Chinese concept of 'natural state of the world'. Thirdly, the differences of historical background, culture and values between the Qing Imperial Garden and the English Landscape Garden. All in all, this research could well invite a more factually-based understanding of the Sino-English architectural interactions as well as the Chinese contributions to the world architecture.
\end{abstract}

\section{INTRODUCTION}

In the 18th century, The Qing Imperial Garden in China and the English Landscape Garden in Britain were the two major peaks of the natural gardens in the history of garden arts and cultural heritage. English Landscape Garden appeared to have drawn on the art of Chinese gardens in the development process. The English or British interest in Chinese gardens may be traced to the $17^{\text {th }}$ century when Sir William Temple (1691) describes the irregular layout of Chinese gardens. This interest developed in the $18^{\text {th }}$ century, as illustrated in a number of publications such as Deigns of Chinese Buildings, Furniture, Dresses, Machines, and Utensils (1757) by William Chambers.

It was more obviously to observed that in the south-east corner of Kew Gardens stands the Great Pagoda(Figure 1) by Sir William Chambers, erected in 1762, from a design in imitation of the Chinese Pagoda(Figure 2).

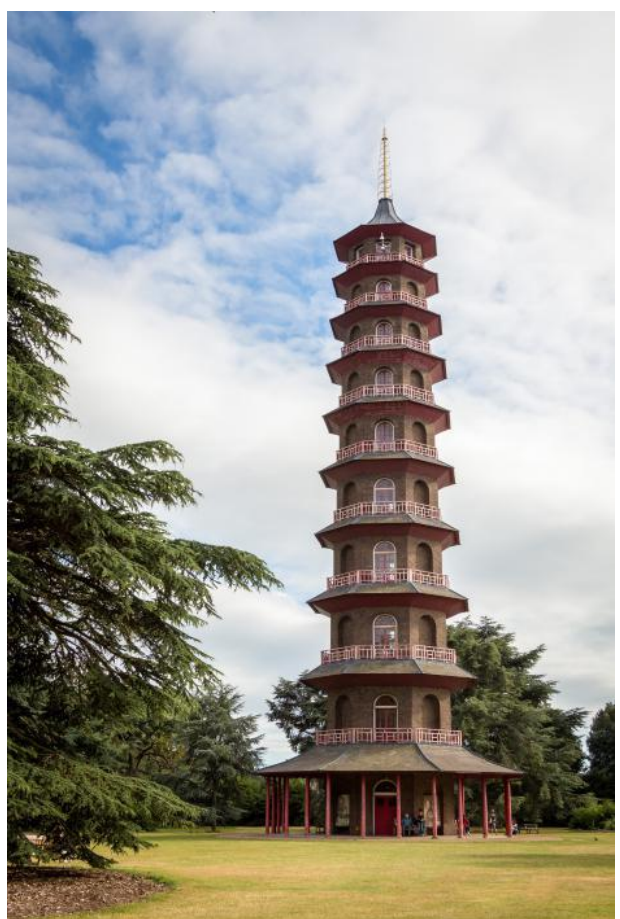

Figure 1. Kew Gardens Great Pagoda Photo by Rafa Esteve in April 2019 


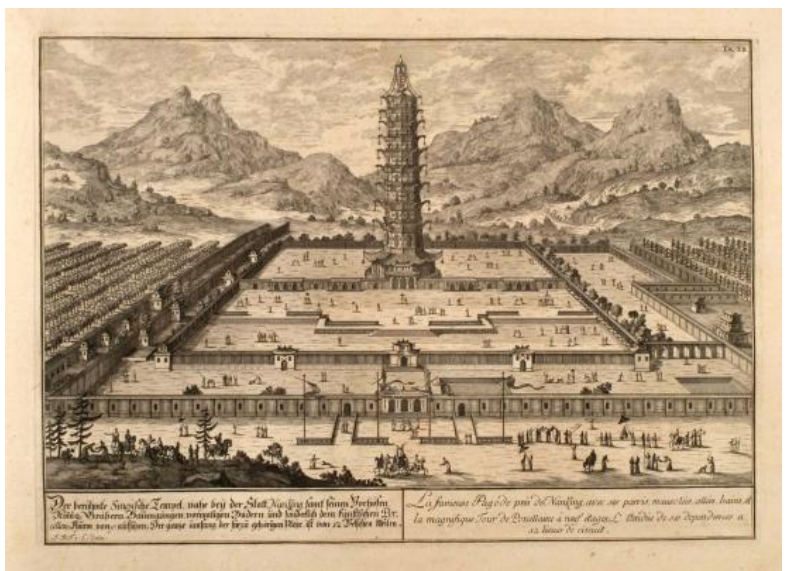

Figure 2. The Porcelain Pagoda as illustrated in Fischer von Erlach's

'Plan of Civil and Historical Architecture' (1721)

Owing to the lack of first-hand materials, English writers attitude to the Qing Imperial Garden in the late $17^{\text {th }}$ to $18^{\text {th }}$ century have not received much attention by scholars in China. With the increasing of cultural exchanges between China and the West, since the early 20th century, the complex relation between $18^{\text {th }}$ century English landscape garden and the Chinese gardens has become an attractive field of modern scholarship. The Chinese Influence on European Garden Structures(1936) for example,written by Eleanor Von Edberg is a famous treatise systematically discussing the impact of traditional Chinese gardens on Europe. Laurence Fleming(1979) believes that the changes in the English Landscape Garden took place quietly and cautiously, but their main ideas are taken from the Qing Imperial Garden. Chen Chunhong(2006) discusses the historical cultural backgrounds and garden art of traditional Chinese garden and the English Landscape Garden. In the same year, Yuan Xuanping in her book discusses Chinoiserie in Britain gardens, and introduced its impact on British interior decoration and furniture. Wu Jiangyang and Jan Woudstra(2015) confirm the key issues directly pushing Chinese gardening features developing in English landscape gardens were the movement of English landscape gardening and the fashion of Chinoiserie.

However, these studies pay little attention to illustrate the inner differences under the surface similarities between the Qing Imperial Garden and the English Landscape Garden in $18^{\text {th }}$ Century. There are three aspects that this project proposes to research. Firstly, the distortion and discontinuity through out the introduction and translation. Secondly, the meaning of 'views of nature' in the English Landscape Garden was inconsistent with the Chinese concept of nature, or 'natural state of the world' in the Qing Imperial Garden. Thirdly, the differences of historical background, culture and values between the Qing Imperial Garden and the English Landscape Garden.

\section{DISTORTION AND DISCONTINUITY}

Europeans were fascinated by reports of the customs and taste of China, mainly issuing from the Jesuit missions there, and the English were no exception, so the information was very scanty.

The westward spread of the Qing Imperial Gardening thoughts in the 18th century was mainly completed by two stages. Firstly, the documents about the Qing Imperial Gardens were translated and explained in French, English and Dutch by Europeans in China. Secondly, these texts of translations and interpretations were 're-interpreted' by local researchers in the UK. The processes of studying the Qing Imperial Gardens westward transmission were basically completed by Europeans. There was no Chinese to the UK to participate in the theoretical construction or the design of the English Landscape Garden.These processes took place in a specific historical period, in which the 'distortions' were limited by various factors: political factors; geographical environment; cultural background; scientific and technological level (such as modes of transportation, information recording and means of communication). The Europeans in China at that time lacked an in-depth understanding of the Chinese philosophical system and historical traditions. The reason why they did not fully understand many key issues was that they cannot understand the cultural context and manifestation of Chinese gardening practice. So the vast majority of the literature they translated is still limited to representations and cannot penetrate the essence of Chinese garden thought.

What's more, the connection between the interpreters, the re-interpreters and the garden designers and builders was severely broken. The key interpreters Michel Benoist(1715-1774), Jean-Denis Attiret(1702-1768) and Pierre-Martial Cibot(1727-1780) have not returned to their hometowns, however, some important re-interpreters such as Sir William Temple(1628-1699), Joseph Addison(1672-1719), Isaac Ware(1704-1766), Horace Walpole(1717-1797) have never gone to China. The latter provides the texts provided by the former for analysis and identification based on first-hand information, so the latter is relevant.There was not only a significant time difference between the theoretical construction and the former's original data, but a lack of scientificity and credibility. Finally, workers who study theoretical communication are also out of touch with garden designers and builders. The transition between theory and practice was ambiguous and even uncertain.

Just as Zhou Ning said:'The image of the Chinese in the Western counties contains three kinds of meaning: one is a reflection of China's reality to a certain extent, the other is the awareness of Sino-Western relations, and the third is the manifestation and refraction of the Western cultural mentality'.

\section{VIEWS OF NATURE AND ZIRANGUAN(自然观) ${ }^{[1]}$}

The idea of ziranguan(自然观) first appeared in the book Laozi, according to which 'natural' means the natural state of things ${ }^{[2]}$.

[1]Tao Te Ching(Also known as: Laozi) says 'There was something undefined and complete, coming into existence before Heaven and Earth. How still it was and formless, standing alone, and undergoing no change, reaching everywhere and in no danger (of being exhausted)! It may be regarded as the Mother of all things.I do not know its name, and I give it the designation of the Dao (the Way or Course). Making an effort (further) to give it a name I call it The Great. Great, it passes on (in constant flow). Passing on, it becomes remote. Having become remote, it returns. Therefore the Tao is great; Heaven is great; Earth is great; and the (sage) king is also great. In the universe there are four that are great, and the (sage) king is one of them. Man takes his law from the Earth, the Earth takes its law from Heaven, Heaven takes its law from the Tao, The law of the Tao is its being what it is'

[2]Tao Te Ching(Also known as: Laozi) says 'All things are produced by the Tao, and nourished by its outflowing operation. They receive their forms according to the nature of each, and are completed according to the circumstances of their condition. Therefore all things without exception honour the Tao, and exalt its outflowing 
While ziranguan(自然观) represents the meaning of santiandi(参天地) ${ }^{[3]}$ in traditional Chinese culture. In 1724 , the Italian priest Matteo Ripa passed through London from China, en route to found a theological college in Naples for the training of Chinese-born priests. It is highly likely that he carried with him a series of copperplate engravings of the imperial garden of Jehol, which he had made on the orders of the Kangxi Emperor ${ }^{[4]}$ in 1713 (Figure $3-4-5$ ). He thought that (Qing Imperial Garden) is in a taste quite different from the European; for whereas we seek to exclude nature by art, leveling hills, drying up lakes, felling trees, bringing paths into a straight line, constructing fountains at a great expense, and raising flowers in rows, the Chinese. on the contrary, by means of art endeavour to imitate nature. ${ }^{[5]}$

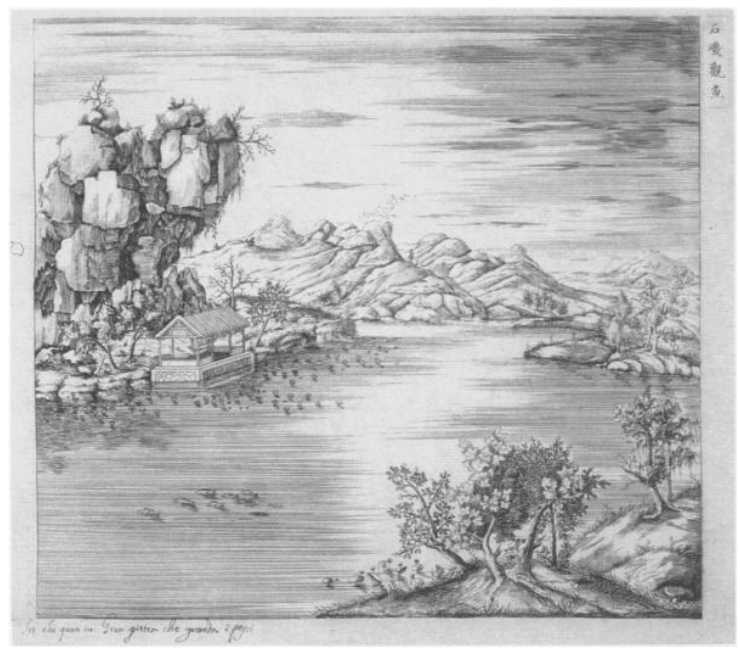

Figure 3. A view of rocks and water at Jehol, drawn by a Chinese artist and engraved by Father Matteo Ripa((1682-1746) in 1713 .

(photo from British Museum)

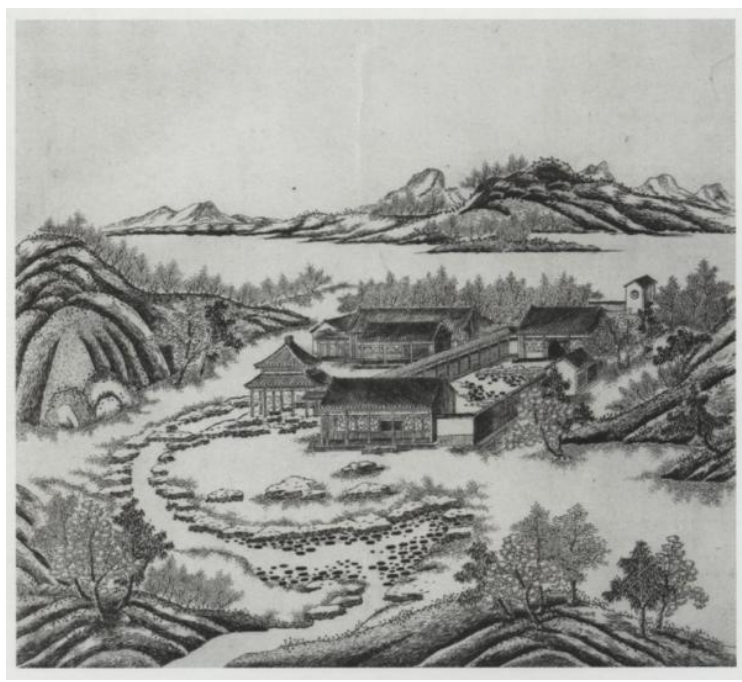

Figure 4. Xiang yuan yi qing, drawn by a Chinese artist and engraved by Father Matteo Ripa (1682-1746) in 1713. (photo from British Museum)

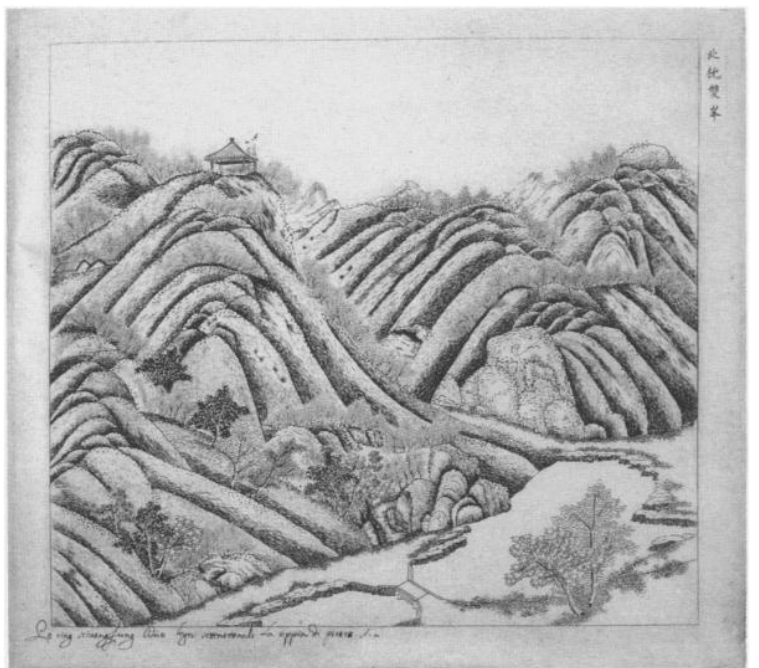

Figure 5. Hills and valleys at Jehol, drawn by a Chinese artist and engraved by Father Matteo Ripa in 1713

(Photo from British Museum)

However, Views of nature in the English Landscape Garden are associated with a variety of European intellectual ideas ranging from the Greco-Roman concept of nature as essence or principle to the Enlightenment credo of nature as liberty. William Kent is among the first to see that 'all nature is a garden' and his famous dictum that 'nature abhors a straight line'(Figure 6 and Figure 7). As for natural garden represented by English Landscape Garden of 18th century, the form and aesthetics of garden can be further divided, 1)ideal nature, like Arcadian garden as paradise, treats the wonderland in ancient legend as desirable environment in new era; 2)in practical nature, mainly involving gardening of farm, it is decoration and beautification of second type of nature in human manufacture, i.e. countryside and wild; 3)in primitive nature, the agitate emotion of this kind of garden is characterized by wildness and precipitousness through little artificial process based on first nature prototype. In these gardens, human life in reality "varnishes". 


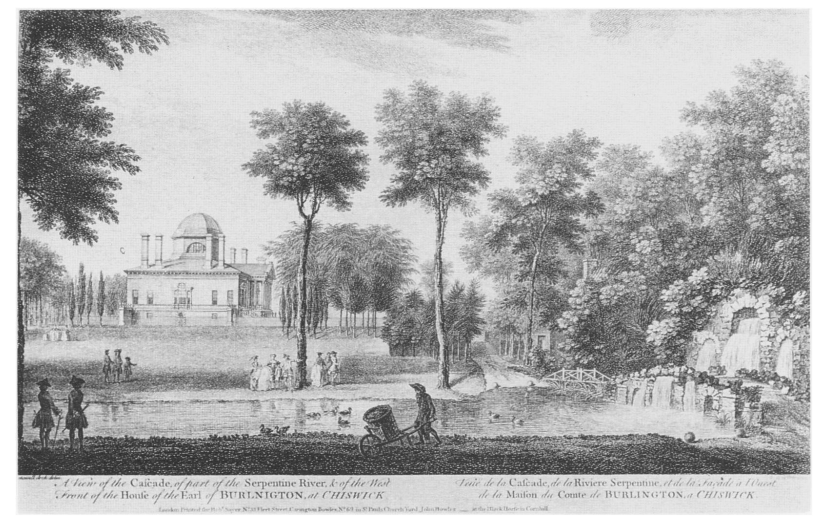

Figure 6. Chiswick House Grounds; the cascade and surroundings, conceived by William Kent in I733 and drawn by Donowell and engraved by Woollett in 1752 . (Photo from David Jacques)

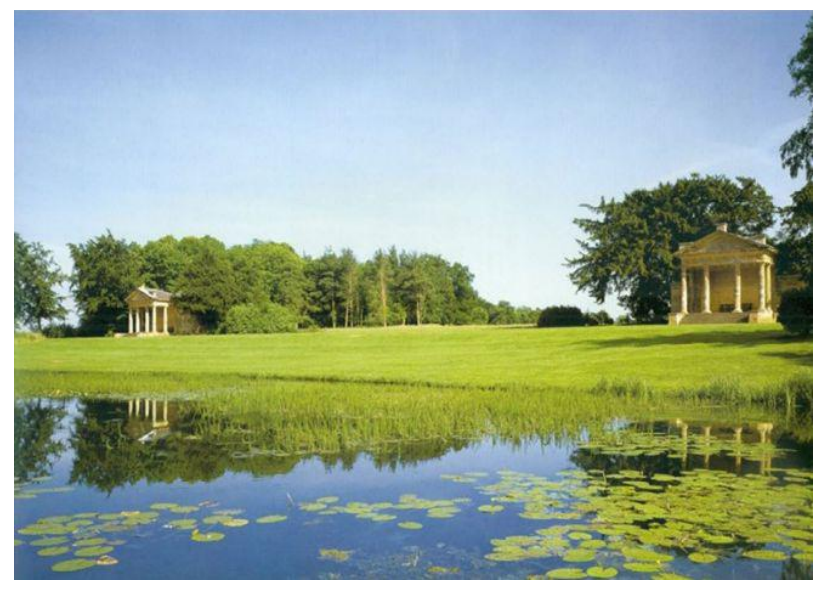

Figure 7. William Kent, Stowe gardens (Photo by Paola Gullino)

\section{CULTURAL HISTORY AND VALUES}

The academic achievements by previous scholars tend to focus on morphological studies and garden layout instead of the differences of culture and values between the Qing Imperial Garden and the English Landscape Garden. So the following study from the viewpoint of philosophy to discuss the differences of cultural origins and values under the superficial likeness in their appearances between those two kinds of gardens. The Qing Imperial Garden and the English Landscape Garden have considerable cultural differences since their historical background and culture traditions were different. The soul of the Qing Imperial Garden's arts were not in the beauty of mountains, water, plants, flowers and architectural combinations, but in the philosophical spirit, ideal personality and yearning for nature. The relationship between man and environment was full of wisdom in the practice of human settlements at different scales. As we all know, the English architects designing landscape gardens such as Stowe House(Figure 8 ) in $18^{\text {th }}$ century did not simply copy traditional Chinese garden elements, but rather they blended the Chinese design methods and the Italian Renaissance gardening tradition.

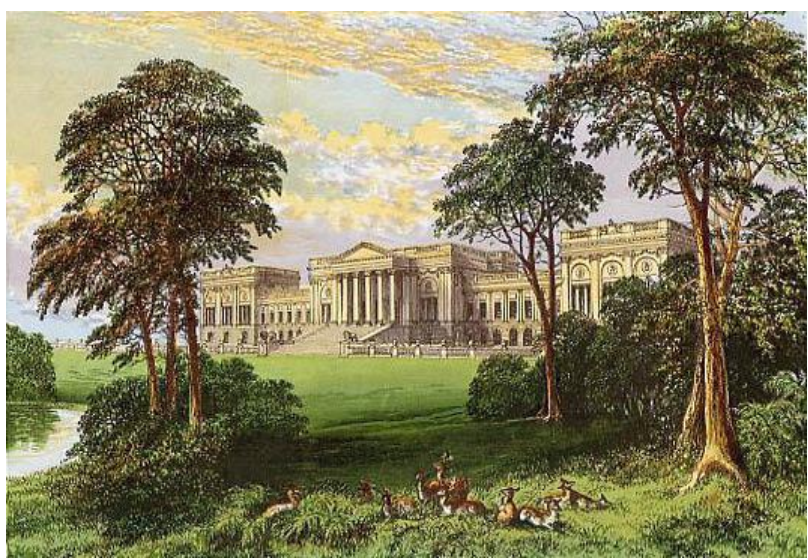

Figure 8. Stowe House in Buckingham shire, England from Morris's 'Country Seats' (1880).

(Photo from Merchbow commonswiki)

Most of the Qing Imperial Garden were presented to people in the form of courtyards. Although they were derived from nature, the gardens were internal and private, and the grass and trees in the gardens emphasized subtle beauty. All the gardens were able to express the infinite artistic conception with limited space and scenery. However, the English Landscape Garden were external and public. In order to make the gardens much better integrated into nature, designers digging ditch instead of building the wall to divide the space. There were no internal and external distinction between the gardens and the outside world. From the rolling grasslands to the meandering rivers, as well as the dense and orderly trees, it seems to be naturally formed and unadorned.

\section{CONCLUSIONS}

Despite the backwardness of traffic and information in the 18th century, the great artistic achievements of Chinese Imperial gardens still promoted the birth and maturity of the garden art, at the other end of Eurasia, in its own unique way.

The translation process was full of information distortion and misunderstanding because of the disconnection between the interpreters, re-interpreters and designers. But the situation was changed from 1793. The fascinating observations on Qing Imperil Garden's culture recorded by the members of the first British Embassy to the Qing dynasty emperor, led by Lord Macartney between 1792 and 1794, have long been overshadowed by the resounding political failure of their mission. That because although the peculiar relationship between the English Landscape Garden and the imperial Chinese examples had been a controversial topic of discussion throughout the 18th century, it was not until 1793 that the ambassador have seen both styles of gardens.

In the process, the essential differences of the concepts toward nature Chinese and Europe under the resemblance and aesthetics between of Chinese garden and English landscape garden was revealed.The English garden designers looked to the Far East as more of a reference to seek justification for their own gardening revolution than a role model for inspiration or imitation. The characteristics of appearance and reproduction of Chinese garden image that spread through commercial and religious paths were reappeared taking the revolution of the English landscape garden into account. Though the existence of misconception can be seen as objective and inevitable, the results of the collision of the two garden cultures were meaningful and gratifying. 


\section{ACKNOWLEDGEMENT}

Project supported by the Major Program of the National Social Science Foundation of China (NO. 14ZDB025), National Natural Science Foundation of China (NO. 51508377) and China Scholarship Council (NO. 201806250156).

\section{REFERENCES}

Aldous Bertram., 2013. Lord Macartney Embassy to Peking, 1793:New light on China and the English landscape garden. The British Art Journal, 14(2), 76-80.

Eleanor Von Erdberg., 1936: Chinese influence on European garden structures. Harvard University Press, Cambridge.

Laozi., 2002: Laozi. China Publishing House, Beijing.

Laurence and Alan Gore Fleming., 1980: The English Garden. Michael Joseph, London.

Matteo Ripa., 1844: Memoirs of Father Ripa, During thirteen Years' Residence at the Court of Peking in the Service of the Emperor of China: With An Account of the Foundation of the College for the Education of Young Chinese at Naples, Fortunato Prandi, London.

Pierre Jean Grosley., 1772: A Tour to London:Volume I. Lockyer Davis, London.

Sir William Temple., 1690: Miscellanea: II-Upon the Gardens of Epicurus Part. Brown T C, London.

Wang Y., 1998. Interior display and its relation to external spaces in traditional Chinese gardens. Studies in the History of Gardens \& Designed Landscapes, 18(3), 232-247.

William Chambers., 1972: Deigns of Chinese Buildings, Furniture, Dresses, Machines and Utensils. North Stratford: Ayer Company Publishers, London.

Wu Jiangyang and Jan Woudstra., 2015. The Rising and Declining of the Chinese Gardening Features in English Landscape Garden. Chinese Lanscape Architecture. 15(2), 84-88.

Zhou Ning., 2006: Western Images of China. Peking University Press, Beijing. 